\title{
Traditional Usages and Phytochemical Screenings of Selected Zingiberaceae from Central Sulawesi, Indonesia
}

\author{
Ramadanil $^{1, *}$, Damry $^{2}$, Rusdi $^{2}$, Baharuddin Hamzah ${ }^{3}$, Muhammad Sulaiman Zubair $^{4}$
}

\section{Ramadanil ${ }^{1, *}$, Damry $^{2}$, Rusdi ${ }^{2}$, Baharuddin Hamzah ${ }^{3}$, Muhammad Sulaiman Zubair ${ }^{4}$}

'Department of Biology, Faculty of Mathemathics and Natural Sciences, Tadulako University, Palu City, Central Sulawesi 94148, INDONESIA.

${ }^{2}$ Department of Animal Husbandry, Faculty of Animal Husbandry and

Fishery, Tadulako University, Palu City, Central Sulawesi 94148, INDONESIA.

${ }^{3}$ Department of Education Chemistry, Faculty of Teaching and Education, Tadulako University, Palu City, Central Sulawesi 94148, INDONESIA.

${ }^{4}$ Department of Pharmacy, Faculty of Mathemathics and Natural Sciences, Tadulako University, Palu City, Central Sulawesi 94148, INDONESIA.

Correspondence

Prof. Ramadanil

Department of Biology, Faculty of Mathemathics and Natural Sciences, Tadulako University, Palu City, Central Sulawesi 94148, INDONESIA

Phone no : +62-0451-85288560451

E-mail: pitopang_64@yoo.com

\section{History}

- Submission Date: 14-11-2018;

- Review completed: 28-01-2019;

- Accepted Date: 12-02-2019

DOI : 10.5530/pj.2019.11.80

Article Available online

http://www.phcogj.com/v11/i3

\section{Copyright}

(C) 2019 Pharmacognosy Journal. This is an open-access article distributed under the terms of the Creative Commons Attribution 4.0 International license.

\begin{abstract}
Background: Zingiberaceae is one of the significant components of the herbaceous ground flora of Southeast Asia tropical forests. This family includes some medicinally important species, in particular the members of genera of Alpinia, Curcuma, Etlingera and Zingiber (Van Balgooy, 2001). Objective: to identify the traditional usages and evaluate for phytochemical screening of selected Zingiberaceae from Central Sulawesi, Indonesia. Material and Methods: Zingiberaceae samples were collected from the Lore Lindu National Park (LLNP), Central Sulawesi Indonesia and its surroundings and evaluated for their phytochemical contents by using TLC method with particular spraying reagents. Results: the plants were used by the local ethnics for different daily and medicinal purposes. All part of each selected species of Zingiberaceae contain flavonoid, tannins, saponins, triterpenoid and alkaloid although steroids were only found in the leaves of Etlingera flexuosa, Curcuma mangga and Alpinia galanga. Alkaloids were only found in the rhyzome of Etlingera flexuosa, Curcuma aerugynosa, Zingiber montanum. Besides it was also detected in leaves of both Alpinia rubricaulis and Etlingera acanthoides. Additionally, Alkaloids were also discovered in the stem of Ammomum aculeata, Alpinia galanga and Curcuma mangga.

Key words: Traditional usages, Phytochemical screening, Zingiberaceae, Central Sulawesi
\end{abstract} Indonesia.

\section{INTRODUCTION}

Sulawesi is well known for its biogeographical wonders. Its location which is to the east of Wallace's line but is close to the Sunda plate and its formation from several separated islands have resulted in an unique taxonomic composition of flowering plants. ${ }^{1}$ The long isolation of the Island and its constituent parts have resulted in a higher rate of endemic taxa both plants and animals in the Island compared to any other islands in the country. Approximately $15 \%$ of the known flowering plant species of Sulawesi are endemic to the Island. ${ }^{2,3}$

Zingiberaceae is one of the flowering plant families and it is the largest family of the order Zingiberales, an aromatic teresterial herb with often large-sized rhizome. It contains 53 genera. ${ }^{4,5}$ It is widely distributed in the (Sub) tropics, particularly as shade plants in evergreen tropical regions, with several genera being of major economic important such as medicinal products, dyes, condiments and spice. Most member of Zingiberaceae are native to Malesia regions and a number of species are grown as ornamental plants in greenhouses and homeyards. ${ }^{6}$

The diversity of Zingiberaceae of Sulawesi and its phytochemical studies are poorly known. ${ }^{7,8}$ A number of systematics studies on the genera of Sulawesi's Zingiberaceae such as Alpinia, Etlingera and Curcuma are still being in progress by botanists. Poulsen $(2012)^{8}$ revisons were made to 48taxa of Etlingera and 36 of which were new species. Zingiber ultralimitale Ardiyani and A.D. Poulsen has reecently been described and barcoded ( $r b c \mathrm{~L}, t r n \mathrm{H}-p s b \mathrm{~A}$ and ITS) and claimed to be a new species occurring on limestone at the Bantimurung National Park, South Sulawesi, Indonesia. ${ }^{9}$ Two new species of Alpinia subsection Cenolophon (A. macrocrista and A. pusilla) from Western Sulawesi have also been described previously. ${ }^{10}$

Phytochemical screening is one important step in the efforts to further explore the potentials of any plant resources. Knowledges of the presence of chemical compounds such as steroids/triterpenoids, alkaloids, phenolic, flavonoids, saponins and tannins in the plants will help us to further characterize the plants for economic uses, for example as medicine, cosmetics and others. ${ }^{11}$

The use of medicinal plants for treating a number of diseases is a primary health care in Indonesia, but the potential of seed plants as a source of new drugs is still largely unexplored. The trend of using naturalproducts has increased and the active plant extracts are frequently screened for new drug discoveries and for the presence of antimicrobial agents ${ }^{11}$ Latest and previous studies have concluded the beneficial
Cite this article: Ramadanil, Damry, Rusdi, Hamzah B, Zubair MS. Traditional Usages and Phytochemical Screenings of Selected Zingiberaceae from Central Sulawesi, Indonesia. Pharmacog J. 2019;11(3):505-10. 
aspects of plant-derived drugs as a good source of antibiotics, ${ }^{12}$ antioxidants ${ }^{13,14}$ and anti-inflammatory agents. ${ }^{15}$

In order to discover and develop new therapeutic agents, a phytochemical study of plants potentially having antimicrobial properties is fundamental. This study was undertaken to screen the phytochemical compounds present in selected species of Zingiberaceae from Central Sulawesi, Indonesia.

\section{MATERIALS AND METHODS}

\section{Plant Materials}

This research was carried out from February to July 2018. Zingiberaceae samples were collected from the Lore Lindu National Park (LLNP), Central Sulawesi, Indonesia and its surroundings (Figure 1). The park is a protected area covering about 220,000 ha and become the habitat of a number of Wallacean endemic plant and animal species. The area has a considerable conservation value and it functions as a watershed protection for the surrounding areas occupied by different ethnics.

A botanical exploration by using the transect methodwas done to study the Zingiberaceae diversity. The observation included vernacular name, scientific name, family, number collection, collector and plant habitus, geographic position (Altitude, latitude and longitude) ecological data of the plants and their daily usage by the local ethnics. All the plant materials collected were identified at the Laboratory of Biodiversity, the Department of Biology, Faculty of Mathematics and Natural Sciences Tadulako University, Indonesia. Plant specimens were determinated using a specimen reference available at the Herbarium Celebence (CEB) of Tadulako University and the specimens identification was done by Zingiberaceae specialists, i.e A.D Poulsen (E) and W. Ardi (BBG-LIPI). All the specimens were mounted, labeled and kept at the CEB.

\section{Plant Extraction}

Plant extraction and phytochemical analyses of all part of each species was conducted at the Laboratory of Phytochemistry, Department of Pharmacy, Faculty of Mathematics and Natural Sciences, Tadulako University.Vegetative organs (Leaves, rhyzome and stem) and inflorescence of all collected species were washed in running tap water three times and cut into $3 \mathrm{~cm}$ pieces and again washed and soaked in running tap water for five minutes then air dried. Fresh and dried leaves, rhyzomes and inflorescence of each species were extracted thrice with 95\% ethanol with maceration. The extracts were filtered, evapourated in a vaccum evaporator and lypholized to give yield of about $60 \mathrm{~g}$ of dry extract.

\section{Phytochemical evaluation}

All part of each species of Zingiberaceae (Leaves, rhyzome and stem) were tested for the presence of various classes of phytochemical compounds such as alkaloid, phenolic compounds, flavonoid, tannins and saponins using standar procedures of analysis. ${ }^{16}$

\section{Test for tannins}

A small quantity of plant extract was mixed with $5 \mathrm{ml}$ of distilled water and heated on a water bath. The mixture was filtered and ferric chloride was added to the filtrate and observed for dark green solutions that indicated the presence of tannin.

\section{Test for flavonoids}

About $0.2 \mathrm{~g}$ of plant extract was weighed in separate test tubes and dissolved in diluted sodium hydroxide. Diluted hydrochloride was added to the solution and observed for yellow solutions that turned colorless. This indicated the presence of flavonoid.

\section{Test for Saponins}

Two $\mathrm{ml}$ of each extract in a test tube was vigourously shaken for two minutes and observed for persistent foaming.

\section{Test for Alkaloids}

About $0.2 \mathrm{~g}$ of plant extract was weighed in separate test tube and warmed with $2 \%$ Sulphuric acid for 2 mins. It was filtered in separate test tube and few drops of Dragencloffs reagent were added and observed for the presence of orange red precipitate for the presence of alkaloid.

\section{Test for Terpenoids}

About $0.5 \mathrm{~g}$ of plant extract in separate test tube was taken with $2 \mathrm{ml}$ of chloroform; $5 \mathrm{ml}$ of concentrated sulphuric acid was carefully added to form a layer and observed for the presence of reddish brown color interface to show positive results for the presence of terpenoid.

\section{Test for Steroids}

Two $\mathrm{ml}$ of acetic anhydride was added to $0.5 \mathrm{~g}$ extract with $2 \mathrm{ml}$ of Sulphuric acid and observed for the color change from violet to blue or green in samples indicating the presence of steroid.

\section{RESULTS AND DISCUSSION}

\section{Traditional use of selected species of Zingiberaceae}

There were Fifteen selected species of Zingiberaceae that were analysed for phytochemical testing and its traditional use information.The list of the species is provided in Table 1 . All the species were selected from our previous research (Pitopang et al. 2018) that reported 24 species of Zingiberaceae and its traditional usage by 3 indigenous tribes living in the surroundings of the Lore Lindu National Park (LLNP), Central Sulawesi, Indonesia.

\section{Chemical Component}

The results of the phytochemical screening on the selected species of Zingiberaceae for the presence of chemical compounds such as tannins, saponins, alkaloids, flavonoids, triterpenoids/steroids are presented in Table 2.

Traditional usages of the selected Zingiberaceae were different significantly among ethnics group (Table 1). Topo Baria ethnic who live in Sedoa valley was the only group that used a few species of Zingiberaceae,

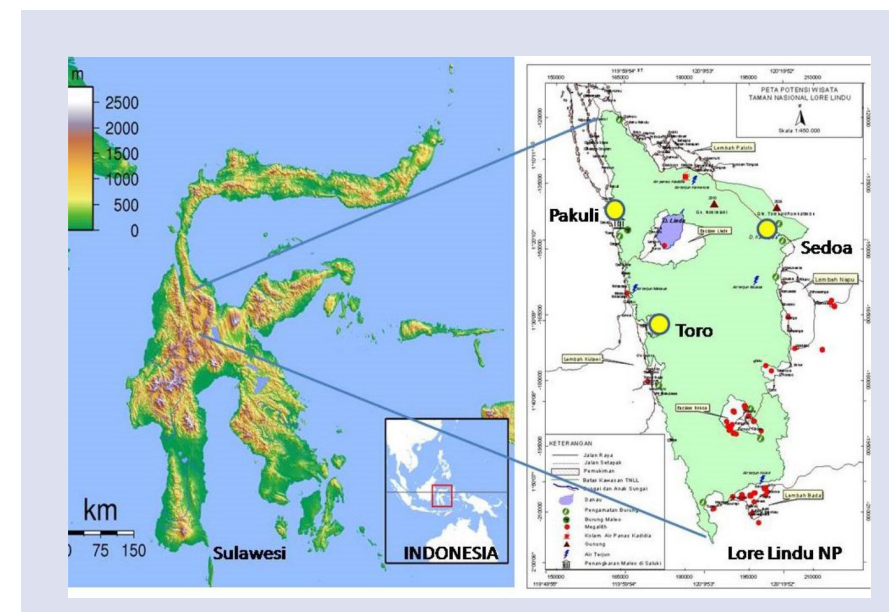

Figure 1: Map of Zingiberaceae Species Collected from Lore Lindu National Park, Central Sulawesi (Yellow Spots). 
Table 1: Fifteen Selected of Zingiberaceae and its Traditional uses by Three Different Indigenous Ethnics who Lives in Lore Lindu National Park, Central Sulawesi, Indonesia (Ramadanil et al. 2018).

\begin{tabular}{|c|c|c|c|}
\hline No & Local name & Scientific name & Usage \\
\hline 1 & Katimba $^{*}$ & Etlingera flexuosa A.D. Poulsen & $\mathrm{Fr}=$ cooking, flavor \\
\hline 2 & Tikala $^{*}$ & Alpinia eremochlamys K. Schum & $\mathrm{Lf}=$ wrapping, tonic \\
\hline 3 & Unknown & Alpinia rubricaulis K. Schum & Unknown \\
\hline 4 & Tikala $^{*}$ & Etlingera acanthoides A.D. Poulsen & $\mathrm{Fr}=$ edible \\
\hline 5 & Tumoni Karondo ${ }^{* *}$ & Hedychium coronarium J. Konig & Rhy=fever,stomach ache, febrifuge, Schistosomiasis \\
\hline 6 & Tikala Bola** & Etlingera elatior (Jack) R.M.Sm. & Infl $=$ vegetable, $\mathrm{Fr}=$ spice \\
\hline 7 & Tikala Walehu** & Ammomum aculeata (Roxb.) Scomix and Newman & Unknown, wild \\
\hline 8 & Tikala tete $^{\star *}$ & Alpinia sp1 & Unknown, wild \\
\hline 9 & Tikala Marangkaleke** & Plagiostachys sp & Unknown, wild \\
\hline 10 & Kuni Vuri*** & Curcuma aerugynosa Roxb. & Rhy $=$ cure of hookworm \\
\hline 11 & Lempuya $^{* * *}$ & Zingiber zerumbet $\mathrm{L}$ & Rhy $=$ cosmetics, rheumatics, stomach, neck problem \\
\hline 12 & Bangle*** & Zingiber montanum (J. Konig) Link ex. A. Dietr & Rhy $=$ menstrual dissorder, stomach ache \\
\hline 13 & Balintua ${ }^{* * *}$ & Alpinia galanga (L.) Willd. & Rhy $=$ dermatomicosis, spice \\
\hline 14 & Kuni Taipa ${ }^{* *}$ & Curcuma mangga Valeton & $\begin{array}{c}\text { Rhy }=\text { Cure for hook worm, antiinflamatory, anticancer, stabilize } \\
\text { menstrual dissorder }\end{array}$ \\
\hline 15 & Kuni $^{* * *}$ & Curcuma longa $\mathrm{L}$ & $\mathrm{Lf}=$ Spice, $\mathrm{Rhy}=\mathrm{HIV}$ treatment, spice, antibactery, infection desease \\
\hline
\end{tabular}

Notes: $\quad *=$ Topo Baria ethnic, ${ }^{* *}=$ Toi Toro Muma, ${ }^{* * *}=$ To Kaili Ledo. Fr.= Fruit, Lf= Leaves, Infl= Inflorescent, Rhy.= Rhyzome.

especially for spice, medicine and wrapping food. They utilized fruit of Etlingera flexuosa and Etlingera acanthoides for cooking fish dishes andas a flavour enhancer. The leaves of Alpinia eremochlamys were also used by the group s food wrappers, while its decoction rhizome was used as a tonic.

On the other side, the Toi Toro Muma at the Western part of the Lore Lindu National Park have used a number species of Zingiberaceae to meet their daily needs such as food, spice, cosmetics, ornamental and medicine. They used the rhyzome of "Tumoni karodo" (Hedychium coronarium) and "Karondo wana" (Hedychium flavescen) as traditional medicines for fever, stomach complaints and schistosomiasis. while "tikala bola" (Etingera elatior) was used as a vegetable.

Meanwhile, the Topo Kaili Ledo useda number species of Zingiberaceae for medicine, spice and cosmetics. They utilized the "Kuni vuri" (Curcuma aerugynosa) for curing the hook worm. Three speciesof Zingiberaceae, namely "Lempuya" (Zingiber zerumbet), 'Bangle" (Zingiber montanum), "Temulawak" (Curcuma zanthorriza) and "Kula" (Zingiber officinale were used as a medication for digestive system disorders. Additionally, "Kuni taipa" (Curcuma mango) and "Kuni" (Curcuma longa) were also utilized for cancer treatment and HIV disease, respectively.

The uses of plant as herbal medicine in the studied area have also been reported by some researchers. For example, Paik et al. (2013) ${ }^{17}$ have described 329 species of medicinal plants from Lore Lindu National Park. Among them were Alpinia eremochlamys, Alpinia sp, Etlingera elatior, Etlingera sp, Curcuma aeruginosa, Curcuma mangga and Hedychium coronarium. Gailea et al. (2016) ${ }^{18}$ who studied the uses of various plant species as medicines by local people in the enclave of Lore Lindu National Park reported that there were 96 species of medicinal plants, among them were Zingiber zerumbet thatwas used for Elephantiasis treatment, Etlingera elatior for Hyperuricemia and a food.

The ethnobotanical studies of Zingiberaceae worldwide were reported by some botanists, incuding on local tribal at Siak Hulu, Kampar district, Riau $^{19}$ and Banjarbaru community, South Kalimantan. ${ }^{20}$ Ethnobotanical, phytochemistry and pharmacological studies of Zingiber cassumunarhave also been reported..$^{21,22}$

This study found that all parts of each species of the selected Zingiberaceae contain flavonoid, tannins, saponins, triterpenoid, alkaloid although steroids were only found in leaves of Etlingera flexuosa, Curcuma mangga and Alpinia galanga. Alkaloids were found in rhyzome of Etlingera flexuosa,Curcuma aerugynosa, Zingiber montanum. They were also detected in leaves of both Alpinia rubricaulis and Etlingera acanthoides. In addition, alkaloids were also discovered in the stem of Ammomum aculeata, Alpinia galanga and Curcuma mangga.

Flavonoids were found in different organs of each plant but mostly found in rhyzome of Etlingera flexuosa, Alpinia rubricaulis, Etlingera acanthoides, Hedicyum coranorium, Etlingera elatior, Curcuma aerugynosa, Zingiber montana and Curcuma longa. Meanwhile, It was also discovered in leaves of Alpinia eremochlamis, Hedycium coronarium, Etlingera elatior, Amomum aculeata, Alpinia sp, Plagiostachys sp, Curcuma aerugynosa, Zingiber montanum, Curcuma mangga and Curcuma longa. Hedcium coranorium, E. elatior leaf were reported to contain flavonoids of kaempferol 3-glucuronide, quercetin 3-glucuronide, quercetin 3-glucoside, quercetin 3-rhamnoside, 3-O-caffeoylquinic acid, 5-O-caffeoylquinic acid (Chlorogenic acid), 5-O-caffeoylquinic acid methyl ester, isoquercitrin, quercitrin and (+)-catechin. ${ }^{23-25}$

Tannins were discovered in all parts of the selected Zingiberaceae organs, except for the rhyzome of Alpinia sp, Plagiostachys and leaves of Curcuma aerugynosa and Zingiber zerumbet.

Saponins were observed in a number of Zingiberaceae species, especially in leaves extract of Etlingera flexuosa, Alpinia eremoclamys, Alpinia rubricaulis, Etlingera acanthoides, Etlingera elatior, Ammomum aculeata, Alpinia sp, Zingiber zerumbet, Zingiber montanum, Alpinia galanga and Curcuma mangga. It was also detected in the rhyzome of Etlingera flexuosa, Alpinia eremoclamis, Hedicyum coronarium, Etlingera elatior, Ammomum aculeatum, Alpinia sp, Curcuma aerugynosa, Zingiber montanum, Alpinia galanga and Curcuma longa. The saponins were also found in the stem of Alpinia eremochlamis, Etlingera acanthoides, 
Table 2: Phytochemical contents of Zinger collections from Central Sulawesi Indonesia.

\begin{tabular}{|c|c|c|c|c|c|c|c|c|}
\hline \multirow{2}{*}{ No } & \multirow{2}{*}{ Botanical name } & \multirow{2}{*}{ Organ } & \multicolumn{6}{|c|}{ Chemical contents } \\
\hline & & & Flavonoid & Tannin & Saponins & Terpenoid & Alkaloid & Steroid \\
\hline \multirow{3}{*}{1} & \multirow{3}{*}{ Etlingera flexuosa A.D. Poulsen } & Leaves & - & + & + & - & - & + \\
\hline & & Stem & - & + & - & + & - & - \\
\hline & & Rhyzome & + & + & + & + & + & - \\
\hline \multirow{3}{*}{2} & \multirow{3}{*}{ Alpinia eremochlamys $\mathrm{K}$. Schum } & Leaves & + & + & + & + & - & - \\
\hline & & Stem & - & + & + & + & - & - \\
\hline & & Rhyzome & + & + & + & - & - & - \\
\hline \multirow{3}{*}{3} & \multirow{3}{*}{ Alpinia rubricaulis K. Schum } & Leaves & + & + & + & + & + & - \\
\hline & & Stem & - & + & + & + & - & - \\
\hline & & Rhyzome & + & + & - & + & - & - \\
\hline \multirow{3}{*}{4} & \multirow{3}{*}{ Etlingera acanthoides A.D. Poulsen } & Leaves & - & - & + & + & + & - \\
\hline & & Stem & - & - & + & + & - & - \\
\hline & & Rhyzome & + & - & - & + & - & - \\
\hline \multirow{3}{*}{5} & \multirow{3}{*}{ Hedychium coronarium J. Konig } & Leaves & + & + & + & + & - & - \\
\hline & & Stem & + & + & - & + & - & - \\
\hline & & Rhyzome & + & + & + & + & - & - \\
\hline \multirow{3}{*}{6} & \multirow{3}{*}{ Etlingera elatior (Jack) R.M.Sm. } & Leaves & + & + & + & + & - & - \\
\hline & & Stem & - & + & + & + & - & - \\
\hline & & Rhyzome & + & + & + & + & - & - \\
\hline \multirow{2}{*}{7} & \multirow{2}{*}{ Ammomum aculeata (Roxb.) Scomix and Newman } & Leaves & + & + & + & - & - & - \\
\hline & & Stem & + & + & + & + & + & - \\
\hline \multirow{3}{*}{8} & \multirow{3}{*}{ Alpinia sp 1} & Leaves & + & + & + & - & - & - \\
\hline & & Stem & - & + & + & + & - & - \\
\hline & & Rhyzome & - & - & + & + & - & - \\
\hline \multirow{2}{*}{9} & \multirow{2}{*}{ Plagiostachys sp } & Leaves & + & + & - & - & - & - \\
\hline & & Stem & - & + & + & + & - & - \\
\hline \multirow{2}{*}{10} & \multirow{2}{*}{ Curcuma aerugynosa Roxb. } & Leaves & + & + & - & + & - & - \\
\hline & & Rhyzome & + & + & + & + & + & - \\
\hline 11 & Zingiber zerumbet L & Leaves & + & + & + & + & - & - \\
\hline & & Rhyzome & + & + & - & + & - & - \\
\hline & & Leaves & + & + & + & + & - & - \\
\hline 12 & Zingiber montanum (J. Konig) Link ex. A. Dietr & Stem & + & - & + & - & - & - \\
\hline & & Rhyzome & + & - & + & + & + & - \\
\hline 13 & Altinia galanga (I) Willd & Leaves & + & + & + & - & - & + \\
\hline & 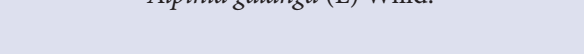 & Stem & - & + & + & - & + & - \\
\hline & & Leaves & + & + & + & - & - & + \\
\hline 14 & Curcuma mangga Valeton & Stem & - & + & + & - & + & - \\
\hline & & Rhyzome & - & + & - & - & - & - \\
\hline 15 & Curcuma longa $\mathrm{L}$ & Leaves & + & + & - & + & - & - \\
\hline & & Rhyzome & + & + & + & + & - & - \\
\hline
\end{tabular}


Hedicyium coranorarium, Etlingera elatior, Amomum aculeata, Alpinia sp, Plagiostachys, Zingiber montanum, Alpinia galanga and Curcuma mangga.

Terpenoid was found in all parts of Hedicyium coranorarium. It had been reported that this plant rich of terpenoid compounds such as diterpenes (Coronarin A, Coronarin B, Coronarin C, Coronarin D and Isocoronarin D), Alcohol terpen (Linalool), Cyclic monoterpen (Limonene), trans-meta-mentha 2,8 diene, $\gamma$-terpinene and 10 -epi- $\gamma$-eudismol. Isocoronarin $\mathrm{D}$ was reported to possess anticancer activity by inhibiting NF-NB. Terpenoid is also responsible for antimicrobial activity. ${ }^{26-28}$

Our study is the first to report the phytochemical compounds that are present in Zingiberaceae species of Sulawesi. Results reported herein are expected to enhance those of similar studies reported previously, for example, the essensial oils from rhyzome of Zingiber officinale var.rubrum, Zingiber amaricans, Kaempferia galanga and Boesenbergia pandurata, ${ }^{29}$ the chemical constituents of the aerial parts of Etlingera brevilabrum, ${ }^{30}$ Dhanik et al. $(2017)^{31}$ that reviewed Zingiber officinale, Joseph et al. $(2015)^{32}$ on the anticonvulsans activity of Zingiber zerumbet and Rannema and Reddy (2017) on the phytochemical investigation of Curcuma caesseafrom different geographical region of India. ${ }^{33}$

Other studies of the Zingiberaceae species focussing on the antibacterial and antioxidant properties of the phytochemical compounds have also been reported. For example, Villaflores et al. (2011) ${ }^{34}$ who worked on the phytoconstituent of Alpinia purpurata and their in vitro inhibitory activity againt Mycobacterium tuberculosis, Tripathi et al. (2013) on the essential oil from the family of Zingiberaceae for antimicrobial activity, ${ }^{35}$ on phytochemical screening and evaluation of its antimicrobial activities of Zingiber officinale, ${ }^{36}$ phytochemical and antimicrobial activities of turmeric, ${ }^{37}$ Ghasemzadeh et al. (2016) on variation of phytochemical constituents and antioxidant activity of Zingiber officinale var. rubrum $^{38}$ and Azam et al. (2014) on the phytochemical screening and antipyretic effect of Curcuma zedoria Rosc. ${ }^{39}$

\section{CONCLUSION}

It was concluded that the plants were used by the local ethnics for different daily and medicinal purposes. All part of each selected species of Zingiberaceae contain flavonoid, tannins, saponins, triterpenoid, alkaloid althought steroids were only found in the leaves of Etlingera flexuosa, Curcuma mangga andAlpinia galanga. Alkaloids were only found in the rhyzome of Etlingera flexuosa, Curcuma aerugynosa, Zingiber montanum. Besides it was also detected in leaves of both Alpinia rubricaulis and Etlingera acanthoides. Additionally, alkaloids were also discovered in the stem of Ammomum aculeata, Alpinia galanga and Curcuma mangga.

\section{ACKNOWLEDGEMENT}

The authors would like to thank the Rector of Tadulako University for the financial support through "Professor Research Program (160.e/ UN28.2/PL/2018). We are also thankful to Ir. Donny M. Mangitung, M.Sc, Ph.D, Prof. Dr. Ir. Syukur Umar and their staffs for organizing this research project, to the Lore Lindu National Park Authority (LLNP) for permission to conduct this research and to Sahlan, SSi, Adhil, SSi, Sucipto, Agung, Eka, Roland Putra and Zulfadly for their kind helps during this study.

\section{CONFLICT OF INTEREST}

The authors declare that there is no conlfict of interest.

\section{ABBREVIATIONS}

LLNP: Lore Lindu National Park; TLC: Thin layer Chromatography; HIV: Human Immunodeficiency Virus.

\section{REFERENCES}

1. Pitopang R, Ramawangsa PA. Potensi Penelitian Etnobotani Di Sulawesi Tengah Indonesia. (Potencial of Ethnobotanical Studies in Central Sulawesi Indonesia). J of Nat Sc. 2016;5(2):111-131.

2. Gradstein SR, Kessler M, Pitopang R. Tree Species Diversity relative to Human Land Uses in Tropical rain forest Margins in Central Sulawesi in Land use and Nature Conservation. Heidelberg, Spinger Verlag. 2007;321-34.

3. Henderson AJ, Pitopang R. The Rattan (Arecaceae) of Wallacea. J Biodiv. 2018;19(1):18-21.

4. Van B, MMJ. Malesian Seed Plants. Potraits non-tree families.Nationaal Herbarium Netherland. Nordic Journal of Botany. 2001;21(6):570.

5. Kress WJ, Liu AZ, Newman MF, Li QJ. The Molecular Phillogeny of Alpinia (Zingiberaceae): a Complex and Polyphilletic Genus of Zingers. Am J of Bot 2005;92(1):167-78.

6. Newman M, Lhuillier A, Poulsen AD. Checklist of the Zingiberaceae of Malesia. J Blum Supplement. 2004;16:165.

7. Ramadanil, Damry, Rusdi, Hamzah B, Zubair MS, Amar AL, et al. Diversity of Zingiberaceae and its Traditional Uses by Three Different Indigenous Ethnics who lives in Lore Lindu National Park, Central Sulawesi Indonesia. Submitted to International Seminar of Sciences and Technology - Palu. 2018.

8. Poulsen AD. Etlingera of Sulawesi (Kota Kinabalu, Sabah, Natural History Publications in association with Royal Botanic Garden Edinburgh and Natural History Museum, University of Oslo). 2012;278.

9. Ardiyani M, Newman MF, Poulsen AD. A new species of Zingiber (Zingiberaceae) east of Wallace's Line. Gard Bull Singapore. 2017;69(2):189-99.

10. Ardi WH, Ardiyani M. Two New Species of Alpinia (Zingiberaceae) from Sulawesi, Indonesia. J of Reinwardtia. 2015;14(2):311-6.

11. Shalini S, Sampathkumar P. Phytochemical screening and antimicrobial activity of plant extracts for disease management. Int J Curr Sci. 2012;1(1):209-18.

12. Nascimento GGF, Locatelli J, Freitas PC, Silva GL. Antibacterial activity of plant extracts and Phytochemicals on antibiotic resistant. Brazilian Journal of Microbiology. 2000;31(4):247-56.

13. Proestos C, Lytoudi K, Mavromelanidou OK, Zoumpoulakis P, Sinanoglou VJ. Antioxidant Capacity of Selected Plant Extracts and their Essensial Oils. Antioxidants. 2013;2(1):11-22.

14. Chirag CJ, Tyagi S, Halligudi N, Yadav J, Pathak S, Sing SP, et al. Antioxidant Activity of Herbal Plants: a Recent Review. J of Drug Discovery and Therapeutics. 2013;1(8):01-08

15. Strzelecka M, Bzowska M, Koziel J, Szuba B, Dubiel O, Nunez DR, et al. Anti-inflammatory Effects of Extracts from some traditional Mediterranean diet plants. J of Physiology and Pharmacology. 2005;56(Suppl 1):139-56.

16. Harborne JB. Metode Fitokimia (Terjemahan). Terbitan ke-2. Publisher ITB. Bandung. 1987.

17. Paik JH, Lee J, Choi S, Marwoto B, Juniarti F, Irawan D, et al. Medicinal of Lore Lindu National Park, Sulawesi Indonesia (Bekasi, PT Alimindo Sejati Indonesia KRIBB-BPPT-Tadulako University). 2013;342.

18. Gailea R, Bratawinata AA, Pitopang $R$, Kusuma IW. The use of various plant types as medicines by local community in the enclave of the Lore Lindu National Park of Central Sulawesi, Indonesia. Global Res Med Plants and Indig Med. 2016;5(1):29-40

19. Auliani A, Fitmawati, Sofiyanti N. Etnobotanical study of Zingiberaceae at the local community in Siak Hulu, Kampar Regency, Riau Province. JOM FMIPA. 2014;1(2):526-33.

20. Kuntorini EM. Botanical Economy of Zingiberaceae as Traditional Medicine by local community at Banjar Baru, South Kalimantan. J Bioscientiae. 2005;3:2536.

21. Singh CB, Manglembi N, Swapana N, Chanu SB. Ethnobotany, Phytochemistry and Pharmacology of Zingiber Pharmacology Roxb. (Zingiberaceae). J of Phar and Phytochem. 2015;4(1):1-6

22. Prakash O, Rajput M, Mahesh K, Pant AK. Chemical Composition and Antibacterial Activity of Rhizome Oils From Hedychium coronarium Koenig and Hedy chium spicatum Buch-Ham. J of Essential Oil Bearing Plants. 2010;13(2):250-9

23. Williams CA, Harborne JB. The leaf flavonoids of Zingiberales. Biochem System Ecol. 1977;5(3):221-9.

24. Chan EWC. Bioactivities and chemical constituents of leaves of some Etlingera species (Zingiberaceae) in Peninsular Malaysia. Monash University Sunway Campus, Malaysia. Ph.D. thesis. 2009. Available from: http://arrow.monash edu.au/hdl/1959.1/149589

25. Chan EWC, Lim YY, Ling SK, Tan SP, Lim KK, Khoo MGH. Caffeoylquinic acids from leaves of Etlingera species (Zingiberaceae). LWT - Food Sci Technol. 2009;42(5):1026-30. 
26. Denise CE, Francisca SNT, Tamara PK, John MP, Fernão CB. Cancer chemoprevention activity of labdane diterpenes from rhizomes of Hedychium coronarium. Brazilian J of Pharmacognosy. 2014;24(1):408-12.

27. Pachurekar P, Dixit AK. A Review on Pharmacognostical Phytochemical and Ethnomedicinal Properties of Hedychium Coronarium J. Koenig an Endangered Medicine. International Journal of Chinese Medicine. 2017:1(2):49-61.

28. Joshi S, Chanotiya CS, Agarwal G, Prakash O, Pant AK, Mathela CS. Terpenoid compositions and antioxidant and antimicrobial properties of the rhizome essential oils of different Hedychium species. Chem Biodivers. 2008;5(2):299-309.

29. Sukari MA, Sharif NWM, Yap ALC, Tang SW, Neoh BK, Rahmani M, et al. Chemical Constituents variantions of Essential oils fromrhyzomes of Four Zingiberaceae Species. The Malaysian J of Analyt Scie. 2008;12(3):638-44.

30. Mahdavi B. Chemical constituents of the aerial parts of Etlingera brevilabrum (Zingiberaceae). Der Pharma Chemica, 2014;6(2):360-5.

31. Dhanik J, Arya N, Nand V. A review of Zingiber officinale. J of Pharmacog and Phytochem. 2017;6(3):174-84.

32. Joseph L, George M, Sreelakshmi R. Phytocehemical and Pharmacological studies on Zingiber zerumbet hydro-alcohol extract for anticonsulvant activity. IJT (International Journal of Therapeutical Application). 2015;29:19-23.

33. Rannema M, Reddy SK. Phytochemical Investigation Study of Curcuma caesea
Roxb. Different Geographical Regions (Delhi and Orissa) of India. J of Biotech and Biochem. 2017;3(1):23-6.

34. Villaflores OB, Macabeo APG, Gehle D, Krohn K, Frauzblau SG, Aquihaldo AM. Phytoconstituents from Alpinia purpurataand their in vitro Inhibitory Activity againts Mycobacterium tuberculosis. Pharmacognosy Magazine. 2011;6(24):339-44.

35. Triphati M, Chawla P, Upadhyay R, Trivedi, S. Essential oils from family Zingiberaceae for anti microbial activity- A review. Int J Pharm Bio Sci. 2013;4 (4):149-62.

36. Bhargava S, Dhabbai K, Batra A, Sharma A, Malhotra B. Zingiber officinale, Chemical and phytochemical screening and evaluation of its antimicrobial activities. J of Chem and Pharma Research. 2012;4(1):360-4.

37. Nisar T, lqbal M, Raza A. Turmeric: A Promising spice for phytochemical and antimicrobial activities. Am-Euras. J Agric and Environ Sci. 2015;15(7):1278-88.

38. Ghasemzadeh A, Jaafar HZE, Rahmat A. Variation of the Phytochemical Constituents and Antioxidant Activity of Zingiber officinale var. rubrum Theilade associated with different drying methods and Polyphenol oxidase activity. Molecules, MDPI. 2016;21(6):780.

39. Azam MG, Noman MS, Al-Amin MM. Phytochemical Screening and antipyretics effect of Curcuma zedoria Rosc. (Zingiberaceae) rhyzome. British J of Pharmacetical Research. 2014;4(5):569-76.

\section{GRAPHICAL ABSTRACT}

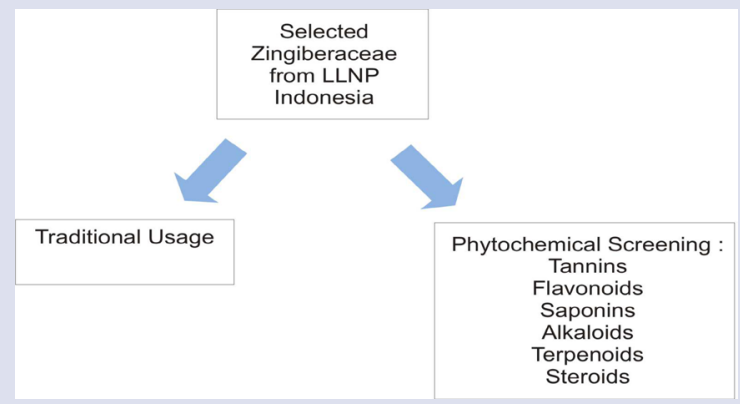

\section{ABOUT AUTHORS}

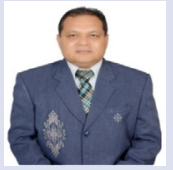

Ramadanil, Professor at Department of Biology, Faculty of Mathematics and Natural Sciences, Tadulako University, Palu, Indonesia. Research area is Plant Taxonomy, Biodiversity Conservation and Ethnobotany

Rusdi, Professor at Department of Chemistry Education, Faculty of Teaching and Education, Tadulako University, Palu, Indonesia. He has research expertise in Animal Feed and Nutrition

\section{SUMMARY}

- All part of each selected species of Zingiberaceae contain flavonoid, tannins, saponins, triterpenoid, alkaloid althought steroids were only found in the leaves of Etlingera flexuosa, Curcuma mangga and Alpinia galanga. Alkaloids were only found in the rhyzome of Etlingera flexuosa, Curcuma aerugynosa, Zingiber montanum.

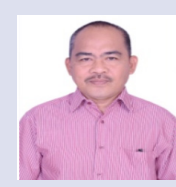

Damry, Professor at Department of Animal Husbandry, Faculty of Animal Husbandry and Fishery, Tadulako University, Palu, Indonesia. He has research expertise in Animal Feeds and Nutrition

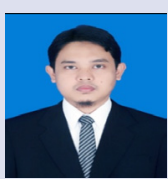

Muhammad Sulaiman Zubair, Associate Professor at Department of Pharmacy, Faculty of Mathematics and Natural Sciences, Tadulako University, Palu, Indonesia. Research area is natural product and medicinal chemistry. Research topics are herbal drug standardization, secondary metabolite isolation, and marine natural products. He also work on computational research such as virtual screening and docking molecular

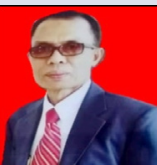

Baharuddin Hamzah, Professor at Department of Chemistry Education, Faculty of Teaching and Education, Tadulako University, Palu, Indonesia. He has research expertise in Organic Chemistry

Cite this article: Ramadanil, Damry, Rusdi, Hamzah B, Zubair MS. Traditional Usages and Phytochemical Screenings of Selected Zingiberaceae from Central Sulawesi, Indonesia. Pharmacog J. 2019;11(3):505-10. 